\title{
New electrode for pacing fetuses with complete heart block
}

\author{
Novo eletrodo para implante de marcapasso em fetos com bloqueio atrioventricular total
}

Renato S. ASSAD ${ }^{1}$, Paulo ZIELINSKY ${ }^{2}$, Renato KALIL ${ }^{2}$, Gustavo LIMA², Anna ARAMAYO ${ }^{2}$, Ari SANTOS ${ }^{2}$, Roberto COSTA ${ }^{1}$, Miguel BARBERO-MARCIAL ${ }^{1}$, Sérgio A. OLIVEIRA ${ }^{1}$

RBCCV 44205-619

\section{Abstract}

Objective: As fetal complete heart block with hydrops carries a poor prognosis, intrauterine pacing appears the most logical treatment. However, premature labor following hysterotomy remains a major obstacle to open procedures. Therefore, we developed a new lead for fetal pacing that avoids the need for intrauterine open surgical procedures.

Methods: We successfully implanted a new T-bar-shaped lead into the myocardium of a fetus at 25 weeks gestation presenting with complete heart block (heart rate $=47$ beats per minute), hydrops, and structural heart defects. The procedure was performed under ultrasound guidance, and the lead was introduced through the tip of a specially designed, $18 G$ needle. The new lead was then connected to a Biotronik Actros pulse generator, which was implanted subcutaneously in the maternal abdominal wall.

Results: The stimulation resistance was $357 \Omega$, and the sensed fetal $R$ wave was $6.4 \mathrm{mV}$. The voltage strength-duration curve remained relatively constant at pulse widths $>0.6 \mathrm{msec}$. An echocardiogram on the first postoperative day revealed a mild pericardial effusion. The fetal heart rate was stable, with low stimulation thresholds and no stimulation failures. No uterine contractions were observed during the postoperative period. However, the fetus died 36 hours after the procedure, probably due to cardiac tamponade.

Conclusion: To our knowledge, this is the first documentation of voltage strength-duration curves for the acute myocardial stimulation threshold of a human fetus that survived 36 hours after intrauterine pacemaker implantation. This case emphasizes that percutaneous fetal pacing with the new lead is feasible and may minimize the chances of premature labor.

Descriptors: Cardiac surgical procedures. Heart block, surgery. Pacemaker artificial. Hydrops fetalis.

\section{Resumo:}

Objetivo: O bloqueio atrioventricular total (BAVT) fetal apresenta mau prognóstico quando associado à hidropsia. $O$ implante de marcapasso no feto a céu aberto pode desencadear

\footnotetext{
1 Heart Institute (InCor) University of Sao Paulo Medical School

2 Institute of Cardiology, Porto Alegre

BRAZIL

Running title: New Lead for Fetal Pacing

Address for reprints:

Renato S. Assad, M.D.

Heart Institute University of Sao Paulo

Division of Pediatric Cardiac Surgery

Av. Dr. Eneas Carvalho Aguiar, 44

Sao Paulo, SP 05403-000 BRAZIL

Phone/FAX: (011) 3069-5089
} 
o trabalho de parto prematuro e suas conseqüências. Por isso, desenvolvemos um novo eletrodo para implante de marcapasso em fetos, que evitaria a operação intra-uterina a céu aberto.

Método: Um novo eletrodo em formato de "T" foi implantado no miocárdio de um feto com 25 semanas de gestação, BAVT $(F C=47 \mathrm{bpm})$, hidropsia e cardiopatia congênita associada. $\mathrm{O}$ procedimento foi realizado com ajuda de ultra-som, sendo o eletrodo veiculado através da ponta de uma agulha 18-G. Após o implante, o eletrodo foi conectado ao analisador de pulsos para avaliação dos limiares e, posteriormente, ao gerador de pulsos Biotronik Actros.

Resultados: A resistência foi de $357 \Omega$ e a onda $R$ foi de 6,4 mV. A curva do limiar de estimulação permaneceu relativamente constante para larguras de pulso acima de 0,6 mseg. O ecocardiograma no $1^{\circ}$ P.O. revelou derrame

\section{INTRODUCTION}

Complete heart block occurs in 4 to $15 \%$ of the cases with fetal arrhythmia. Although it is usually well tolerated in the absence of complicating cardiac anomalies, as many as $25 \%$ of these fetuses develop hydrops and die in utero, specially those cases with a heart rate of less than 55 beats per minute, regardless of the presence or absence of an associated structural heart defect [1-3]. In this situation, medical treatment with positive chronotropic drugs or steroids usually fails [4-6]. The pathophysiologic arguments for fetal ventricular pacing are compelling. However, prenatal pacing through a cesarean section might provoke pre-term labor and delivery, which is not desirable in a fetus with congestive heart failure and immature lungs. At present, ineffective pharmacological control of uterine contractility after fetal open surgery is a common problem and remains the major obstacle to prenatal intervention [7].

On the other hand, puncture of the amniotic cavity poses a small risk of fetal loss, which is estimated to be approximately $0.5 \%$ [8]. With appropriate equipment and expertise, sonographically guided puncture of the myocardium for electrode implantation could be probably performed with a low risk of fetal loss.

We describe the case of a fetus presenting with complete heart block, hydrops, and associated structural heart defects, whose mother consented to attempts at in utero pacing. The purpose of this paper is to describe a new lead for percutaneous implantation, which minimizes surgical trauma to both the fetus and mother. pericárdico discreto. A freqüência cardíaca fetal permaneceu estável, com baixos limiares de estimulação e sem perda de comando. Não foram observadas contrações uterinas durante o pós-operatório. Entretanto, o feto foi a óbito 36 horas após o procedimento, provavelmente por tamponamento cardíaco.

Conclusões: Este caso representa a primeira documentação de limiares agudos de estimulação de um feto humano que sobreviveu 36 horas ao implante de marcapasso intra-uterino. Este caso enfatiza que o implante de marcapasso fetal percutâneo é factível e pode minimizar as chances de trabalho de parto prematuro.

Descritores: Procedimentos cirúrgicos cardíacos. Bloqueio cardíaco, cirurgia. Marcapasso artificial. Hidropsia fetal.

\section{CASEHISTORY}

A 36 year-old woman was referred to the Institute of Cardiology Porto Alegre at 18 weeks gestation with a fetus with complete heart block (heart rate $=47$ beats per minute) and marked hydrops, left atrial isomerism, and an atrioventricular septal defect. Maternal therapy with positive chronotropic drugs and steroids did not reverse the low output failure and low fetal heart rate. A follow-up maternal ultrasound examination at 24 weeks gestation suggested depressed right ventricular contractility in the fetus and abdominal and pleural effusions.

With the risk of fetal demise approaching $100 \%$, fetal pacing was considered. After extensive discussions with the physicians involved with the Fetal Cardiology Research Program of the Heart Institute, University of Sao Paulo and the Institute of Cardiology Porto Alegre, including explanation of the procedure's benefits and risks, the patient consented to attempts at in utero transthoracic fetal ventricular pacing. The procedure was performed at 25 weeks gestation according to a protocol approved by our institutional's ethics committee on human research.

\section{Anesthesia}

The mother was sedated with intravenous midazolam and fentanyl citrate. Xylocaine $1 \%$ was infiltrated subcutaneously in her abdomen in preparation for chordocentesis. The placental cord was then punctured transplacentally, under ultrasound guidance, using an 18-gauge needle. Pancuronium and ketamine were administered to the fetus.

The new lead

We recently designed a prototype T-shaped lead that 
can be introduced via an 18-gauge needle to fix securely in the fetal myocardium, with no need for open surgical procedures. The lead represents a modification of the temporary epicardial pacing lead commonly used after heart surgery. The main difference is that at the cardiac end, the pacing lead is cut close to the polypropylene coating and a stainless steel metal bar $(5 \mathrm{~mm} \times 0.5 \mathrm{~mm})$ is connected to the wire, producing a T-bar. The purpose of this shape is to keep the new lead securely anchored to the myocardium, thus, preventing lead dislodgement. The other end of the lead remains intact, consisting of a long straight needle.

In the present case, the new pacing lead was driven to the heart of the fetus through the tip of a specially designed, 15 -cm, 18-gauge introducer needle with a $25^{\circ}$-beveled tip. This tip contained a 7-mm longitudinal side slot cut from the heel of the bevel that housed the T-bar. The T-bar was positioned within the lumen at the tip of the needle, and the pacing wire protruded from the slot and trailed alongside the needle (Figure 1). Use of a needle stylet was planned to eject the T-bar from the slot.

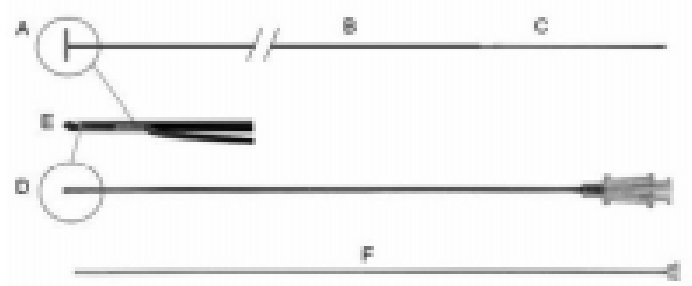

Fig. 1 - The introducer needle with the new T-bar lead. (A) Stainless steel bar. (B) Pacing wire with polypropylene coating. (C). Straight needle. (D) 18-gauge introducer needle with a $25^{\circ}$ beveled tip, fashioned with a 7-mm longitudinal side slot cut from the heel of the bevel $(E) .(F)$ Needle stylet.

\section{Fetal Pacing Procedure}

The site for lead introduction was marked on the mother's abdomen and local anesthesia was applied. Under continuous scanning, the new lead was inserted into the uterine cavity and advanced into the fetal thorax and then the ventricle. The fetus was in the dorsal presentation, making it difficult to reach the ventricles. After four attempts, the needle tip hit the myocardium. The needle stylet was gently advanced into the needle lumen, and the T-bar lead was ejected from the introducer needle slot into the myocardium by pressing the needle stylet forward. The introducer needle was then withdrawn. A second lead was placed in the thoracic wall for bipolar stimulation. The leads were then connected to the pacing system analyzer (Biotronik ERA 300, Berlin, Germany) to measure the sensitivity and stimulation thresholds. Ventricular pacing was begun at 140 beats/min. Stimulation resistance was measured during constant-voltage pacing $(5 \mathrm{~V})$ at $0.5 \mathrm{msec}$ pulse duration. We measured a stimulation resistance of $357 \Omega$ and a sensed fetal $\mathrm{R}$ wave of $6.4 \mathrm{mV}$. During the procedure, the fetus developed cardiac tamponade, managed with pericardiocentesis.

\section{Fetal Myocardial Stimulation Threshold}

Measurements were made at constant pulse width pacing until the lowest output provided $100 \%$ ventricular capture. Stimulation thresholds were obtained at pulse width ranging from 0.1 to $2.0 \mathrm{msec}$, by gradually decreasing the voltage output of the pulse analyzer to the point where ventricular non-capture was apparent with bradycardia. The acute fetal myocardial stimulation thresholds were consistently low, with no stimulation failure seen with the new electrode. The curve remained relatively constant at pulse widths greater than $0.6 \mathrm{msec}$, turning sharply upward with shorter pulse widths less than $0.6 \mathrm{msec}$.

After all measurements, the leads were connected to a Biotronik Actros SR single-chamber pulse generator, which was implanted subcutaneously in the maternal abdominal wall. The pacemaker was set to the following parameters: VVI mode, pacing rate 140 pulses/min, cardiac sensitivity $1.25 \mathrm{mV}$, cardiac pulse amplitude $5.0 \mathrm{~V}$, and refractory period $400 \mathrm{msec}$.

In the first postoperative day, the echocardiogram revealed recovery of ventricular function, a stable fetal heart rate of $140 \mathrm{bpm}$ and mild pericardial effusion (figure 2).

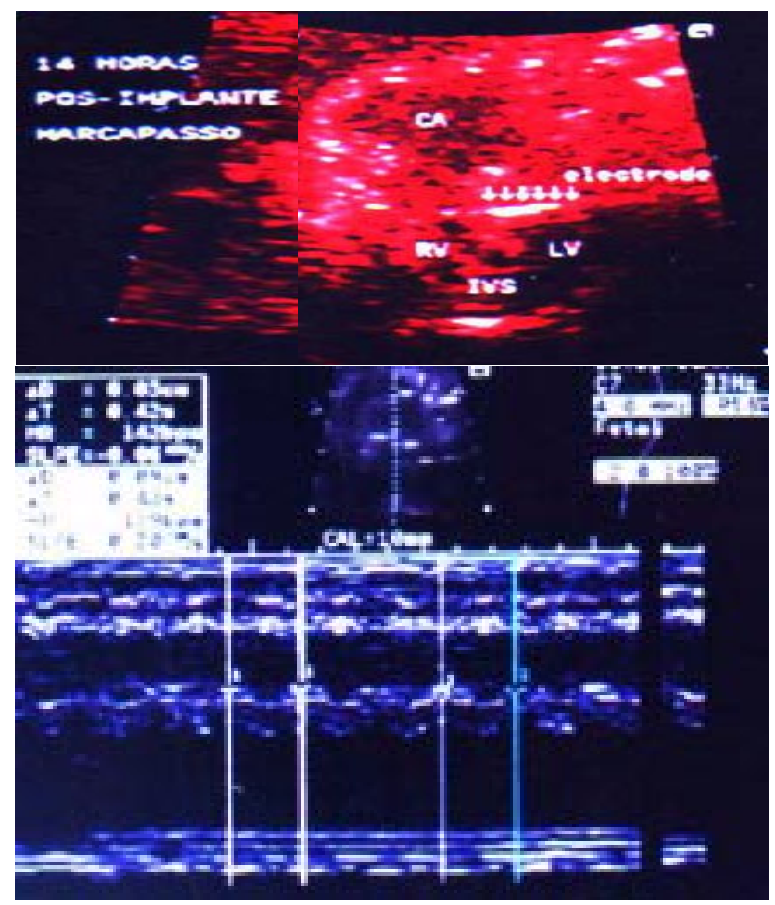

Fig. 2 - Echocardiogram (first postoperative day) revealed recovery of ventricular function, a stable fetal heart rate of $140 \mathrm{bpm}$ and mild pericardial effusion. 
No uterine contractions were observed in the postoperative period. Again, low stimulation thresholds and no stimulation failures were seen. Figure 3 shows the voltage strength-duration curves obtained during the implantation procedure and on the first postoperative day. After 36 hours of ventricular pacing, asystole was noticed on ultrasound and the pericardial effusion appeared significant. The pregnancy was subsequently terminated through a cesarean section, resulting in the delivery of an $800 \mathrm{~g}$ hydropic infant.

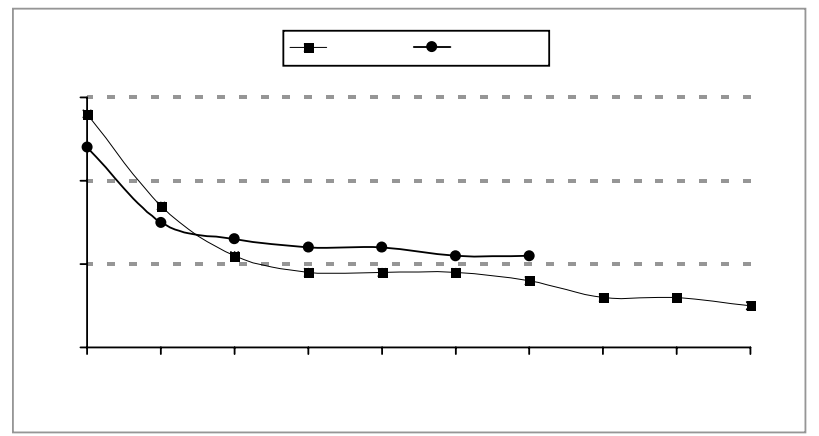

Fig. 3 - Voltage strength-duration curves for acute myocardial stimulation threshold of a human fetus during lead implant and first postoperative day (POD). The acute fetal myocardial stimulation thresholds were consistently low, with no stimulation failure seen with the new electrode. The curve remained relatively constant at pulse widths greater than 0.6 msec, turning sharply upward with shorter pulse widths less than $0.6 \mathrm{msec}$.

\section{Fetal Autopsy}

Postmortem examination confirmed massive hydrops and cardiac anatomic defects. A moderate bloody effusion in the pericardial sac was considered the probable cause of fetal death. One pacing lead was firmly placed in the left ventricle's muscle, and the other lead was as well placed in the thoracic wall. No hematoma was observed in the ventricular wall nor thrombi within the ventricles.

\section{DISCUSSION}

The T-bar lead proposed here for use in percutaneous fetal pacing may offer important technical advantages over leads used in conventional open surgical procedures. During the observed period of fetal pacing, our lead provided stable fixation with acceptable performance, demonstrated by the low acute thresholds. Indeed, we believe that this is the first documentation of the voltage strength-duration curves for acute myocardial stimulation threshold of a human fetus that survived 36 hours after intrauterine pacemaker implantation. Moreover, this technique has the potential to minimize surgical trauma to both the fetus and mother.

The cardiac tamponade observed in this case could have resulted from the three failed attempts at lead placement. We believe that use of fetoscopy in conjunction with ultrasound guidance would allow for a more controlled procedure in which the new lead could be placed more easily [9]. In addition, the development of improved materials, such as a thinner needle (20-gauge) and a bipolar pacing wire, could facilitate puncture of the fetal myocardium, thus, decrease the chances of such a complication.

In the present case, the fetal heart rate was abruptly increased from 47 to 140 beats per minute with pacing. Nevertheless, bradyarrhythmia with a heart rate of $50 \%$ of normal fetal rate is well tolerated in the absence of complicating systemic abnormalities or placental insufficiency. Therefore, it seems to us that a gradual increase in the fetal rate would be more adaptive and could adequately augment the cardiac output as well. It also is unclear whether such a jump in the fetal heart rate could result in any acidbase imbalances due to increasing myocardial oxygen consumption and cardiac output. Further investigation of different pacing rates on fetal cardiac output and metabolism has been undertaken in our laboratory using a model of complete AV block in fetal lambs[10].

Previous attempts at in utero percutaneous pacing, either via a transthoracic approach [11] or through the inferior vena cava [12], have resulted in fetal demise a few hours after the procedure. A lack of myocardial fixation and consequent dislodgement of the percutaneous lead represents a major technical limitation of the percutaneous approach. Although the authors have demonstrated that the pacing wires can be satisfactorily positioned within the heart, they could not prevent dislodgement with resumption of fetal activity. Our new prototype lead has the length increased from $60 \mathrm{~cm}$ to $150 \mathrm{~cm}$ in order to avoid this problem.

Attempts at direct pacemaker implantation through a cesarean section were undertaken at the University of California, San Francisco [13] and at the Institute of Cardiology Porto Alegre, both unsuccessful.

In our previous experimental study [14], we described the use of an epicardial modified screw-in lead to pace fetuses with complete heart block through a cesarean section as a safer and more reliable procedure. However, the possibility of premature labor still represents a challenge for fetal surgery [15]. The percutaneous approach associated with this new lead for fetal ventricular pacing seems to be more compelling and less invasive. Moreover, it should be a relatively inexpensive, simple, and quick alternative to classic surgical placement of an epicardial lead. Complications will probably decrease as experience increases and materials improve. However, this procedure must be based on a very critical risk/benefit analysis, considering maternal surgical risk as well as the potential salvage of the fetus with $\mathrm{CHB}$ and hydrops. 


\section{ACKNOWLEDGEMENTS}

The authors wish to thank Dr. Jose A. Ramirez, Director of the Heart Institute (InCor) University of Sao Paulo Medical School, for facilitating the agreement between the two involved institutions. This agreement permitted this successful collaborative effort at fetal pacing to occur.

\section{BIBLIOGRAPHIC REFERENCES}

1. Schmidt KG, Ulmer HE, Silverman NH, Kleinman CS, Copel JA. Perinatal outcome of fetal complete atrioventricular block: a multicenter experience. J Am Coll Cardiol 1991;17:1360-6.

2. Huhta JC, Strasburger JF, Carpenter RJ, Reiter A, Abinader E. Pulsed Doppler fetal echocardiography. J Clin Ultrasound 1985; 13:247-54.

3. Kleinman CS, Donnerstein RL, Jaffe CC, DeVore GR, Weinstein EM, Lynch DC et al. Fetal echocardiography: a tool for evaluation of in utero cardiac arrhythmias and monitoring of in utero therapy: analysis of 71 patients. Am J Cardiol 1983; 51:237-43.

4. Machado MV, Tynan MJ, Curry PV, Allan LD. Fetal complete heart block. Br Heart J 1988; 60:512-5.

5. Crowley DC, Dick M, Rayburn WF, Rosenthal A. Twodimensional and M-mode echocardiographic evaluation of fetal arrhythmia. Clin Cardiol 1985;8:1-10.

6. Bierman FZ, Baxi L, Jaffe I, Driscoll J. Fetal hydrops and congenital complete heart block: response to maternal steroid therapy. J Pediatr 1988;112:646-8.
7. Harrison MR, Longaker MT. Maternal risk and the development of fetal surgery. In: Harrison MR, Golbus MS, Filly RA, editores. The unborn patient: prenatal diagnosis and treatment. Philadelphia: W.B. Saunders; 1991. p.189-202.

8. Golbus MS, Loughman WD, Epstein CJ, Halbasch G, Stephens JD, Hall BD. Prenatal genetic diagnosis in 3000 amniocenteses. N Engl J Med 1979; 300:157-63.

9. Kohl T, Strumper D, Witteler R, Merschhoff G, Alexiene R, Callenbeck $\mathrm{C}$ et al. Fetoscopic direct fetal cardiac access in sheep: an important experimental milestone along the route to human fetal cardiac intervention. Circulation 2000; 102:1602-4.

10. Assad RS, Aiello VD, Jatene MB, Costa R, Hanley FL, Jatene AD. Cryosurgical ablation of fetal atrioventricular node: new model to treat fetal malignant tachyarrhythmias. Ann Thorac Surg 1995;60(6 Suppl):S629-32.

11. Carpenter Jr. RJ, Strasbuerger JF, Garson Jr. A, Smith RT, Deter RL, Engelhardt Jr. HT. Fetal ventricular pacing for hydrops secondary to complete atrioventricular block. J Am Coll Cardiol 1986; 8:1434-6.

12. Walkinshaw SA, Welch CR, McCormack J, Walsh K. In utero pacing for fetal congenital heart block. Fetal Diagn Ther 1994; 9:183-5.

13. Silverman NH, Kohl T, Harrison MR, Hanley FL. Experimental fetal surgery in the animal model and in the human fetus. In: Imai Y, Momma K, editores. Proceedings of the Second World Congress of Pediatric Cardiology and Cardiac Surgery. Armonk: Futura Publishing, 1998.p.622-3.

14. Assad RS, Jatene MB, Moreira LF, Sales PC, Costa R, Hanley FL et al. Fetal heart block: a new experimental model to assess fetal pacing. Pacing Clin Electrophysiol 1994;17:1256-63.

15. Longaker MT, Golbus MS, Filly RA, Rosen MA, Chang SW, Harrison MR. Maternal outcome after open fetal surgery: a review of the first 17 human cases. JAMA 1991; 265:737-41. 